\title{
Risk Factors for Mortality by Novel Corona Virus Disease, in Mexico: A Cross-Sectional Study
}

\author{
Nicolás Padilla-Raygoza ${ }^{1, *}$, Cuauhtémoc Sandoval-Salazar², Ma Guadalupe León-Verdín ${ }^{3}$, \\ María de Jesús Gallardo-Luna ${ }^{3}$, Efraín Navarro-Olivos ${ }^{3}$, Francisco J. Magos-Vazquez ${ }^{3}$, Daniel \\ Alberto Díaz-Martínez ${ }^{3}$ \\ ${ }^{1}$ School of Medicine, University of Celaya, Celaya, México \\ ${ }^{2}$ Department of Nursing and Obstetrics, Division of Health Sciences and Engineering, Campus Celaya- \\ Salvatierra, University of Guanajuato, Celaya, Mexico \\ ${ }^{3}$ Institute of Public Health from Guanajuato State, Guanajuato, Mexico
}

*Corresponding Author: Nicolás Padilla-Raygoza, School of Medicine, University of Celaya, Celaya, México, E-mail: padillawarm@gmail.com

\begin{abstract}
The emergence of the Severe Acute Respiratory Syndrome Coronavirus 2 (SARS-CoV-2) infection epidemic in China alerted countries to the possibility of spread of the epidemic and Mexico was no exception. With a slow start, to date there were 120,102 confirmed cases.The objective was to analyze the effect of underlying pathologies in the presence of Coronovaris Infectious Disease -19 (COVID-19) on the possibility of dying in the Mexican population. Ancross-sectional study was conducted using the open database of the National Epidemiological Surveillance System (NESS) of the General Directorate of Epidemiology (GDE) to analyze the mortality of patients infected with SARS-CoV-2 and with disease due to COVID-19.Logistic regression models were generated for co-morbidities (diabetes, obstructive pulmonary disease, chronic, asthma, immunosuppression, hypertension, cardiovascular disease, chronic kidney disease, obesity, and smoking) and death, and differences in proportions were calculated between having the different co-morbidities. morbidities and die.The sample was 120,102 records, of which 14,053 (11.7\%) had died and there were statistically significant differences $(P<.05)$ between having co-morbidities and dying. All co-morbidities had ORs greater than 1, except asthma.Age and gender showed a confounding effect. Having a comorbidity and having COVID-19, increases the possibility of dying in the Mexican population.
\end{abstract}

Keywords: Coronavirus; diabetes; hypertension; mortality

\section{INTRODUCTION}

In December 2019, cases of unknown cause pneumonia are reported in Wuhan, Hubei Province, China [1]. As of June 8, 2020, the World Health Organization (WHO) reports almost 7 million infected and just over 400,000 deaths in 216 affected countries worldwide [2].

The causative virus, when identified, was called 2019- novel Coronavirus and later, the WHO called it Severe Acute Respiratory Syndrome Coronavirus 2 (SARS-CoV-2) [3].

Coronaviruses belong to the Coronaviridae family in the Nidovirales order. Corona represents crown-like spikes on the outer surface of the virus; thus, it was named as a coronavirus. Coronaviruses are small (65-125 $\mathrm{nm}$ in diameter) and contain a single-stranded
RNA as a nucleic material, size ranging from 26 to $32 \mathrm{kbs}$ in length [4].

The zoonotic origin of SARS-CoV-2 has not been confirmed, however sequential analysis suggests bats as their reservoir; DNA recombination was found to be involved in the spine glycoprotein which classifies SARS-CoV, thus being the reason for cross-transmission between species and rapid infection. According to phylogenetic branches, SAR-CoV-2 is close to SARS.CoV of bats [4].

The virus was identified and characterized by Zhu et al, and also, confirmed that SARS-CoV2 , uses the same cell entry receptor, Angiotensin-Converting Enzyme 2 (ACE2), as SARS-CoV, which is highly expressed in airway epithelial cells [5]. 
It has been reported that the virus remains until the second week after the attack in mild cases and in severe cases it remains in the body for up to three weeks. The permanence of the virus was longer in men and in those over 60 years of age; in feces from 17 to 31 days, in respiratory tract from 13 to 29 days in plasma from 11 to 21 days [6].

According to Phan [7], he reviewed the SARSCoV-2 genome, recovered from patients from China, the USA, Australia, Japan, France, Singapore, England, Taiwan, South Korea, Belgium, Germany and Vietnam and its alignment sequence of nucleotides revealed 93 mutations, eight of which corresponded to the surface spine glycoprotein and this is the target of neutralizing antibodies [8] SARS-CoV-2 enters mucous membranes mainly nose and larynx and up to the lungs; the initial symptoms are fever and cough [9], it passes into the circulation, causing viremia; it attacks target organs that express ACE2, such as the lungs, kidney, heart, and gastrointestinal tract $[10,11]$. It is speculated that B lymphocytes could decrease by affecting the production of antibodies [12], and the inflammation factors, mainly Interleukin-6, increase contributing to the worsening of the disease, 7 - 14 days after the attack [13] and the phase Clinic is divided into three stages: viremia, acute and recovery phases; if the patient is older or has immunocompromise and is accompanied by other diseases such as diabetes, hypertension, the immune system does not control the virus in the acute phase and becomes a critical patient [13].

Therefore, the objective was to analyze the evolution of the spread of COVID-19, as well as its mortality and comorbidities and its effect on death, in the Mexican population until June 8, 2020.

\section{MeTHODS}

A cross-sectional study was designed with the data included in the NESS/GDE database published on June 8, 2020 [14].

The study was approved by the Ethics Committee of the Celaya-Salvatierra Campus of the University of Guanajuato, with an expedited review and not requiring informed consent because only the database was worked and no personal data was collected, with the registry CBCCS- 05130042020.

The data included in the database are: age, gender, date of onset of symptoms, date of death if it occurred, presence of diabetes, COPD, asthma, immunosuppression, hypertension, cardiovascular disease, chronic kidney disease, obesity, smoking, Real Time-Polymerase Chain Reaction (RT-PCR) result for SARS-CoV-2.

In Mexico, a suspicious case was considered to be one with cough, fever, dyspnea, contact with a case and/or having traveled to a country affected by the pandemic.

A confirmed case was one that was a suspicious case and that the RT-PCR test was positive for SARS-CoV-2.

Confirmed cases in which the presence of comorbidities was unknown were eliminated from the analysis for underlying pathologies, but not from the initial analysis.

Descriptive statistics were used for all variables. $\mathrm{Z}$ was used for two proportions and a $\mathrm{P}$ value to check sex differences between the deceased and the non-deceased, and Student's Ttest and P value for two means to check differences in average age.

To analyze the co-morbidities with COVID-19 mortality, $\mathrm{Z}$ was used for two proportions and a $P$ value.

Logistic regression models were generated between each co-morbidity and mortality from COVID-19. These models were adjusted for age and gender, and the Likelihood Odds Ratio Test (LRT) was used to compare the models.

In all cases the value of $\alpha=0.05$. Statistical analysis was performed in STATA $13.0 \AA$ (Stata Corp. College Station, TX, USA)

\section{RESUltS}

Table 1. Distribution by sociodemographic characteristics by deaths of confirmed cases of COVID-19, Mexico $(n=120,102)$

\begin{tabular}{|c|c|c|c|c|}
\hline $\begin{array}{c}\text { Variab } \\
\text { le }\end{array}$ & \begin{tabular}{c} 
Deaths \\
$(\mathrm{n}=14,05$ \\
\multicolumn{3}{c}{ 3) } \\
$\begin{array}{l}\text { n } \\
\end{array}$
\end{tabular} & 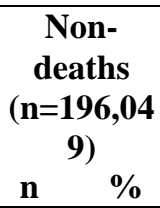 & & \\
\hline $\begin{array}{c}\text { Gender } \\
\text { Male } \\
\text { Female }\end{array}$ & $\begin{array}{l}9,324 \\
66.35 \\
4,729 \\
33.65\end{array}$ & $\begin{array}{c}57,801 \\
54.50 \\
48,248 \\
45,50\end{array}$ & $\begin{array}{c}Z= \\
26.59\end{array}$ & $\begin{array}{c}P= \\
.0000 \\
1\end{array}$ \\
\hline $\begin{array}{l}\text { Age } \\
\text { (years) } \\
\text { Range } \\
\quad \text { Mean } \\
\pm \text { S }\end{array}$ & $\begin{array}{c}0 \text { to } 103 \\
60.36 \pm \\
14.23\end{array}$ & $\begin{array}{c}0 \text { to } 120 \\
44.13 \pm \\
15.37\end{array}$ & $\begin{array}{c}\mathrm{t}=118 . \\
65 \mathrm{df} \\
120,46 \\
0\end{array}$ & $\begin{array}{c}P= \\
.0000 \\
1\end{array}$ \\
\hline
\end{tabular}




\section{S standard deviation}

\section{Source: NESS/GDE [14]}

The public database of confirmed cases of COVID-19 in Mexico published on June 8, 2020 [14], includes 120,102 people, of which 14,053 had died, with a specific mortality rate of $11.70 \%$.

Table 1 shows the distribution of confirmed cases of COVID-19, by gender, age, and death. In both the deceased and the non-deceased, men predominated and the differences are significant $(\mathrm{P}<.05)$ : The average age was higher among the deceased and the difference in the average age is significant $(\mathrm{P}<.05)$.

Figure 1 shows the curve of confirmed cases per day; the highest number of cases is between May 14 and 24, 2020; the date corresponds to the start of clinical data and the decrease in cases in late May and early June, could be an artifact due to the delay in the delivery of RTPCR results and their report to NESS/GDE.

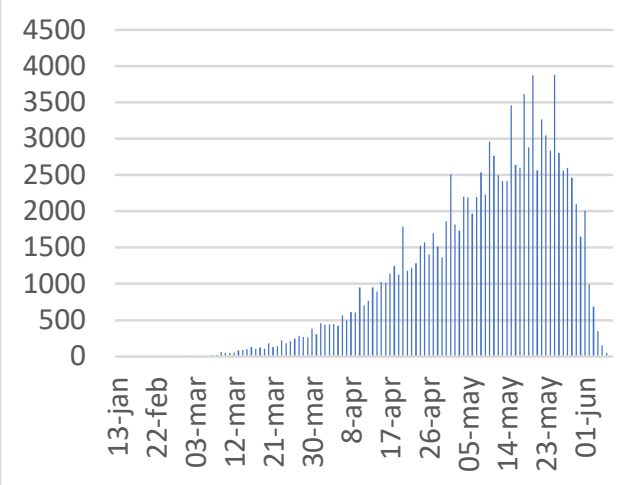

Source: NESS/GDE [14]

Figure 1. Confirmed cases of COVID-19 per day $(n=120,102)$

Figure 2 shows the distribution of COVID19 cases that died, and the highest number of deaths have been from May 14 to June 1, 2020. The decrease in deaths after June 1, could be an artifact due to the delay of notifications to NESS/GDE.

With the data from the public database of the NESS/GDE from June 8, 2020 [14], they were divided into two groups; one for the deceased and the rest for the undead, but all confirmed as cases of COVID- 19 .

For analysis of the effect of co-morbidities on COVID-19 mortality, records were removed from the database where it was unknown if the patients had each condition.
Table 2 shows the cases eliminated by illness and by deceased and non-deceased. The proportion of records deleted in almost all cases were less than $1 \%$.

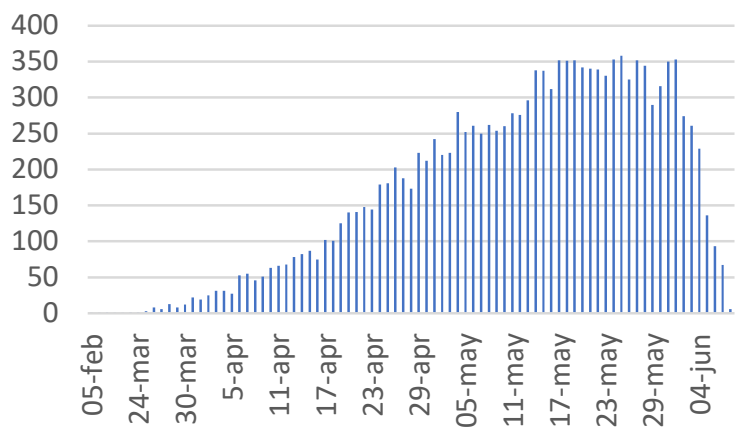

Source: NESS/GDE [14]

Figure 2. Deaths attributed to COVID-19 per day (n $=14,953)$

Table 2. Distribution of registries eliminated by death and by co-morbidities $(n=120,102)$

\begin{tabular}{|c|c|c|}
\hline & $\begin{array}{c}\text { Deaths (n } \\
\% 0\end{array}$ & $\begin{array}{c}\text { Non-deaths } \\
\text { (n \%) }\end{array}$ \\
\hline Diabetes & 1120.80 & $498 \quad 0.47$ \\
\hline COPD & 1160.83 & 4510.43 \\
\hline Asthma & 1130.08 & 4610.04 \\
\hline Immunosuppression & 1210.86 & $506 \quad 0.48$ \\
\hline Hypertension & $107 \quad 0.76$ & $482 \quad 0.45$ \\
\hline $\begin{array}{l}\text { Cardiovascular } \\
\text { disease }\end{array}$ & 1280.09 & 4740.04 \\
\hline $\begin{array}{l}\text { Chronic kidney } \\
\text { disease }\end{array}$ & 1170.08 & 4740.04 \\
\hline Obesity & 1541.10 & 4810.45 \\
\hline Smoking & 1200.85 & 5090.48 \\
\hline
\end{tabular}

Source: NESS/GDE [14]

Table 3 shows the distribution of comorbidities and deaths, as well as $\mathrm{z}$ for two proportions, finding that for all comorbidities, significant differences were found $(\mathrm{P}<.05)$ between deceased and nondeceased, showing the importance of these co-morbidities on COVID-19 mortality.

Table 3. Distribution of deaths by co-morbidities in confirmed cases of COVID-19 in Mexico $(n=120,102)$

\begin{tabular}{|l|c|c|c|c|}
\hline $\begin{array}{c}\text { Co- } \\
\text { morbidities }\end{array}$ & $\begin{array}{c}\text { Deaths } \\
\text { n \% }\end{array}$ & $\begin{array}{c}\text { Non- } \\
\text { deaths } \\
\text { n \% }\end{array}$ & $\mathbf{Z}$ & $\begin{array}{c}\text { P- } \\
\text { value }\end{array}$ \\
\hline Diabetes & & & & \\
Yes & 5,244 & 15,087 & 68.9 & .0000 \\
No & 37.62 & 14.29 & 3 & 1 \\
& 8,697 & 90,464 & & \\
& 62.38 & 85.71 & & \\
\hline COPD & 7395.30 & 1,540 & 31.1 & .0000 \\
Yes & 739 & &
\end{tabular}


Risk Factors for Mortality by Novel Corona Virus Disease, in Mexico: A Cross-Sectional Study

\begin{tabular}{|c|c|c|c|c|}
\hline No & $\begin{array}{c}13,198 \\
94.70\end{array}$ & $\begin{array}{c}1.46 \\
104,05 \\
8 \\
98.54 \\
\end{array}$ & 5 & 1 \\
\hline $\begin{array}{l}\text { Asthma } \\
\text { Yes } \\
\text { No }\end{array}$ & $\begin{array}{c}3092.22 \\
13,631 \\
97.78\end{array}$ & $\begin{array}{c}3,108 \\
2.94 \\
102,48 \\
0 \\
97.06\end{array}$ & $\begin{array}{c}- \\
4.80\end{array}$ & $\begin{array}{c}.0000 \\
1\end{array}$ \\
\hline $\begin{array}{l}\text { Immunosup } \\
\text { pression } \\
\text { Yes } \\
\text { No }\end{array}$ & $\begin{array}{c}4183.00 \\
13,514 \\
97.00\end{array}$ & $\begin{array}{c}1,395 \\
1.32 \\
104,14 \\
8 \\
98.68\end{array}$ & $\begin{array}{c}15.2 \\
5\end{array}$ & $\begin{array}{c}.0000 \\
1\end{array}$ \\
\hline $\begin{array}{l}\text { Hypertensio } \\
\text { n } \\
\text { Yes } \\
\text { No }\end{array}$ & $\begin{array}{l}5,917 \\
42.43 \\
8,029 \\
57.57 \\
\end{array}$ & $\begin{array}{c}18,635 \\
17.65 \\
86,932 \\
82.35 \\
\end{array}$ & $\begin{array}{c}68.0 \\
8\end{array}$ & $\begin{array}{c}.0000 \\
1\end{array}$ \\
\hline $\begin{array}{l}\text { Cardiovascu } \\
\text { lar disease } \\
\text { Yes } \\
\text { No }\end{array}$ & $\begin{array}{c}7915.68 \\
13,134 \\
94.32\end{array}$ & $\begin{array}{c}2,215 \\
2.10 \\
103,36 \\
0\end{array}$ & $\begin{array}{c}25.3 \\
5\end{array}$ & $\begin{array}{c}.0000 \\
1\end{array}$ \\
\hline $\begin{array}{l}\text { Chronic } \\
\text { kidney } \\
\text { disease } \\
\text { Yes } \\
\text { No }\end{array}$ & $\begin{array}{c}978 \quad 7.02 \\
12,958 \\
92.98\end{array}$ & $\begin{array}{c}1,755 \\
1.66 \\
103,82 \\
0 \\
98.34\end{array}$ & $\begin{array}{c}39.8 \\
0\end{array}$ & $\begin{array}{c}.0000 \\
1\end{array}$ \\
\hline $\begin{array}{c}\text { Obesity } \\
\text { Yes } \\
\text { No }\end{array}$ & $\begin{array}{c}3,650 \\
26.26 \\
10,249 \\
73.74\end{array}$ & $\begin{array}{c}20,658 \\
19.57 \\
84,910 \\
80.43\end{array}$ & $\begin{array}{c}18.4 \\
2\end{array}$ & $\begin{array}{c}.0000 \\
1\end{array}$ \\
\hline $\begin{array}{c}\text { Smoking } \\
\text { Yes } \\
\text { No }\end{array}$ & $\begin{array}{c}1,297 \\
9.31 \\
12,636 \\
90.69\end{array}$ & $\begin{array}{c}8,504 \\
8.06 \\
97,036 \\
91.04\end{array}$ & 5.05 & $\begin{array}{c}.0000 \\
1\end{array}$ \\
\hline
\end{tabular}

Source: NESS/GDE [14]

Table 4. Crude logistic regression models adjusted for age and gender between co-morbidities and deaths from COVID-19 in Mexico.

\begin{tabular}{|l|c|c|c|}
\hline & $\begin{array}{c}\text { OR } \\
(\mathbf{C I 9 5 \% )}\end{array}$ & $\begin{array}{c}\text { OR } \\
\text { (CI95\%) } \\
\text { adjusted } \\
\text { by age }\end{array}$ & $\begin{array}{c}\text { OR } \\
\text { (CI95 } \\
\text { \%) } \\
\text { adjuste } \\
\text { d by } \\
\text { gender }\end{array}$ \\
\hline Diabetes & $3.62(3.45-$ & 1.97 & 3.63 \\
& $3.76)$ & $(1.89-$ & $(3.50-$ \\
& & $2.05)^{*}$ & $3.78)^{*}$ \\
\hline COPD & $3.78(3.46$ & 1.37 & 3.87 \\
& $-4.14)$ & $(1.24-$ & $(3.54-$ \\
& & $1.51)^{*}$ & $4.24)^{*}$ \\
\hline Asthma & $0.7 \mathrm{~h} 5(0.66$ & 0.92 & 0.80 \\
& $-0.84)$ & $(0.81-$ & $(0.71-$ \\
& & $1.04)^{*}$ & $0.90)^{*}$ \\
\hline
\end{tabular}

\begin{tabular}{|l|c|c|c|}
\hline Immunosuppr & $2.31(2.07$ & 1.80 & 2.39 \\
ession & $-2.58)$ & $(1.60-$ & $(2.14-$ \\
& & $2.04)^{*}$ & $2.67)^{*}$ \\
\hline Hypertension & $3.44(3.31$ & 1.60 & 3.49 \\
& $-3.57)$ & $(1.53-$ & $(3.36-$ \\
& & $1.66)^{*}$ & $3.62)^{*}$ \\
\hline Heart disease & $2.81(2.59$ & 1.29 & 2.81 \\
& $-3.05)$ & $(1.18-$ & $(2.58-$ \\
& & $1.42)^{*}$ & $3.05)^{*}$ \\
\hline Chronic & $4.46(4.12$ & 3.00 & 4.47 \\
kidney & $-4.84)$ & $(2.75-$ & $(4.12-$ \\
disease & & $3.28)^{*}$ & $4.84)^{*}$ \\
\hline Obesity & $1.46(1.41$ & 1.51 & 1.49 \\
& $-1.52)$ & $(1.45-$ & $(1.43-$ \\
& & $1.58)^{*}$ & $1.56)^{*}$ \\
\hline Smoking & $1.17(1.10$ & 1.18 & 1.02 \\
& $-1.25)$ & $(1.11-$ & $(1.02-$ \\
& & $1.26)^{*}$ & $1.03)^{*}$ \\
\hline
\end{tabular}

* Likelihood Ratio Test $P<.05$ OR Odds Ratio Source: NESS/GDE [14]

Logistic regression models show a significant effect of diabetes, COPD, immunosuppression, hypertension, cardiovascular disease, chronic kidney disease, and obesity with ORs greater than 1. In all comorbidities, age and gender acted as confounders with $\mathrm{P}<.05$, comparing the models. Separate mention is the asthma that seemed to have a preventive effect of dying, but disappears when adjusting for age (Table 4).

\section{DisCUSSION}

The sample of 120,102 confirmed to have COVID-19 in the Mexican population was dominated by men, both in those who died $(66.35 \%)$ and in those who did not die $(54.50 \%)$. The average age was higher among the deceased $(60.36 \pm 14.23$ years $)$ than in the non-deceased $(4.13 \pm 15.37$ years $)(P<.05)$ (Table 1). This confirms that the age of 60 or more years becomes a risk factor for dying from COVID-19 [15], also confirmed by Zhou et al [16], because reported 191 infected by COVID, had increase risk to death with higher age.

In Mexico, the specific mortality rate was $11.70 \%$. In Italy, as of June 3, 2020, the specific mortality rate per case $13.8 \%$ and for those over 60 years of age was much higher than the rest of the ages of those infected with SARS-CoV-2 [15]. European countries show an increase in case-specific mortality for all countries, with Italy and the Netherlands having the highest rates [17]. 
In New York, Petrilli, et al [18], reported as risk factors for a more severe SARS-CoV-2 infection that requires hospitalization were being male, age over 44 years, heart failure, chronic kidney disease and BMI $>40 \mathrm{~kg} / \mathrm{m} 2$ and for a more severe infection it was heart failure, chronic kidney disease and obesity. Older age, hypertension can develop severe COVID-19 and patients male, with heart disease and hyperglycemia have more risk to death [19],

In Mexican population, asthma does have preventive effect on death by COVID-19 (Table3). The same result was reported by Padilla et al, in Mexican population with data from May 2020, on asthma and death by COVID-19 [20]. Although, according to the United States Center for Disease Control and Prevention, risk factors are age greater than 65 years, chronic lung disease, immune suppression from any source, serious heart disease, severe obesity, chronic kidney disease, and severe asthma [21].

\section{CONCLUSION}

The spread of COVID-19 continues to manifest itself in Mexico, with the increase of new cases every day. The role of co-morbidities and age on mortality from COVID-19 is verified. An important fact is the protective effect of asthma on COVID-19 mortality in this sample of the Mexican population.

\section{REFERENCES}

[1] Lu H., Stratton CW., Tang YW. Outbreak of pneumonia of unknown etiology in Wuhan, China: the mystery and the miracle.J Med Virol. 2020;92(4): pp.401-402 (2020). Doi: https://doi.org/10.1002/jmv.25678.

[2] World Health Organization. Coronavirus disease (COVID-19) Situation Report - 140. 2020. Accesed June 13, 2020. Available in: https://www.who.int/docs/defaultsource/coronaviruse/situationreports/20200608-covid-19-sitrep140.pdf?sfvrsn=2f310900_2

[3] World Health Organization. Naming the coronavirus disease (COVID-19) and the virus that causes it. Accessed June 12, 2020. Available in: https://www.who.int/emergencies/diseases/nove 1-coronavirus-2019/technical-guidance/namingthe-coronavirus-disease-(covid-2019)-and-thevirus-that-causes-it

[4] Shereen M.A., Khan S., Kazmi A., Bashir N., Siddiquea R. COVID-19 infection: Origin, transmission, and characteristics of human coronaviruses.J Adv Res.24: pp. 91-98 (2020). Doi: https://doi.org/10.1016/j.jare.2020.03.005
[5] Zhu N., Zhang D., Wang W., Li X., Yang B., Song J., et al.A novel coronavirus from patients with pneumonia in China, 2019 [published online ahead of print January 24, 2020]. N Engl J Med. https://doi.org/10.1056/NEJMoa2001017

[6] Zheng S., Fan J., Yu F., Feng B., Lou B., Zou Q., et al.Viral load dynamics and disease severity in patients infected with SARS-CoV-2 in Zhejiang province, China, January-March 2020: retrospective cohort study. BMJ, 369:m1443. (2020)doi: https://doi.org/10.1136/ bmj.m1443

[7] Phan F. Genetic diversity and evolution of SARS-CoV-2. Infect Genet Evol.81: 104260. (2020)doi:https://doi.org/10.1016/ j.meegid. 202 0.104260

[8] Yu F., Du L., Ojcius DM., Pan C., Jiang S. Measures for diagnosing and treating infections by a novel coronavirus responsible for a pneumonia outbreak originating in Wuhan, China. Microbes Infect.22(2):pp.74-79. (2020) Doi: https://doi.org/10.1016/j.micinf.2020.01.003 .

[9] Guan W.J., Ni Z.Y., Hu Y., Liang W., Ou C., He J.,et al.Clinical characteristics of 2019 novel coronavirus infection in China.N Engl J Med.382: pp.1708-1720. (2020) Doi: https://doi.org/10.1056/NEJMoa2002032

[10] Harmer D., Gilbert M., Borman R., Clark KL. Quantitative mRNA Expression Profiling of ACE 2, a Novel Homologue of Angiotensin Converting Enzyme.FEBS Lett.532(1-2):pp. 107-110. (2002) Doi: https://doi.org/10.1016 /s0014-5793(02)03640-2

[11] Letko M., Marzi A., Munster V. Functional assessment of cell entry and receptor usage for SARS-CoV-2 and other lineage B betacoronaviruses.Nat Microbiol.5:pp. 562-569. (2020) Doi: https://doi.org/10.1038/s41564-0200688-y .

[12] Lin L., Lu L., Cao W., Li T. Hypothesis for potential pathogenesis of SARS-CoV-2 infection-a review of immune changes in patients with viral pneumonia. Emerg Microbes Infect. 9(1):pp. 727-732. (2020) Doi: https://doi.org/10.1080/22221751.2020.1746199

[13] Wan S.X., Yi Q.J., Fan S.B.,Lv J., Zhang X., Gui L., et al.Characteristics of lymphocyte subsets and cytokines in peripheral blood of 123 hospitalized patients with 2019 novel coronavirus pneumonia (NCP).medRxiv. 2020; Doi: https://doi.org/10.1101/2020.02.10.20021832 .

[14] National Epidemiological Surveillance System/ General Directorate of Epidemiology. Secretary of Health (Mexico). Accessed June 8, 2020. Available in:http://www.sinave.gob.mx/

[15] Coronavirus (COVID-19) death rate in Italy as of June 3, 2020, by age group. Statista. 2020. Accesed 12 june 2020. Available in: 
https://www.statista.com/statistics/1106372/cor onavirus-death-rate-by-age-group-italy/

[16] [Zhou F., Yu T., Du R., Fan G., Liu Y., Liu Z., et al.Clinical course and risk factors for mortality of adult inpatients with COVID-19 in Wuhan, China: a retrospective cohort study.Lancet.395: pp.1054-1062. (2020), Doi: https://doi.org/10.1016/S0140-6736(20)30566-3

[17] Natale F., Ghio D., Tarchi D., Goujon A., Conte A. COVID-19 Cases and Case Fatality Rate by age. European Comission. 2020 Accesed June 12, 2020. Available in: https://ec.europa.eu/ knowledge4policy/sites/know4pol/files/jrc1204 20_covid_risk_and_age.pdf

[18] Petrilli C.M., Jones S.A., Yang J., Rajagopalan H., O’Donnell L., Chernyak Y., et al.Factors associated with hospital admission and critical illness among 5279 people with coronavirus disease 2019 in New York City: prospective cohort study. BMJ.369:m1966. (2020).doi: https://doi.org/10.1136/bmj.m1966

[19] Li X., Xu S., Yu M., Wang K., Tao Y., Zhou Y., et al.Risk factors for severity and mortality in adult COVID-19 inpatients in Wuhan. $\mathbf{J}$ Allergy Clin Immunol.146 (1):pp.110-118. (202 0);Doi: https://doi.org/10.1016/ j.jaci. 2020 .04 .006

[20] Padilla-Raygoza N., Sandoval-Salazar C., DíazBecerril L.A., Beltrán-Campos V.,

[21] Díaz-Martínez D.A., Navarro-Olivos E., et al Update of the evolution of SARS-CoV-2 infection, COVID-19, and mortality in Mexico until May 15, 2020: An ecological study.International Journal of TROPICAL DISEASE \& Health. 41(5):36-45 (2020). Doi: https://doi.org/10.9734/IJTDH/2020/v41i53027 7

[22] CDC. People Who Are at Higher Risk for Severe Illness Coronavirus Disease 2019 (COVID-19). 2020. Accessed Jun 12, 2020. Available in: https://www.cdc.gov/ coronavirus/ 2019-ncov/need-extra-precautions/ people-athigherrisk.html?CDC_AA_refVal =https\% 3A $\% 2 \mathrm{~F} \% 2 \mathrm{Fwww} . c d c$.gov\%2Fcorona virus $\% 2 \mathrm{~F} 20$ 19-ncov\%2Fhcp\%2Funderlying-conditions.html

Citation: Nicolás Padilla-Raygoza, Cuauhtémoc Sandoval-Salazar, Ma Guadalupe León-Verdín, María de Jesús Gallardo-Luna, Efraín Navarro-Olivos, Francisco J. Magos-Vazquez, Daniel Alberto Díaz-Martínez. Risk Factors for Mortality by Novel Corona Virus Disease, in Mexico: A Cross-Sectional Study. ARC Journal of Public Health and Community Medicine. 2020;5(3):14-19.DOI: dx.doi. org /10.20431/2456-0596.0503002.

Copyright: () 2020 Authors. This is an open-access article distributed under the terms of the Creative Commons Attribution License, which permits unrestricted use, distribution, and reproduction in any medium, provided the original author and source are credited. 